Portland State University

PDXScholar

$1-2020$

\title{
Do Farmers Manage weeds on Owned and Rented Land Differently? Evidence from U.S. Corn and Soybean Farms
}

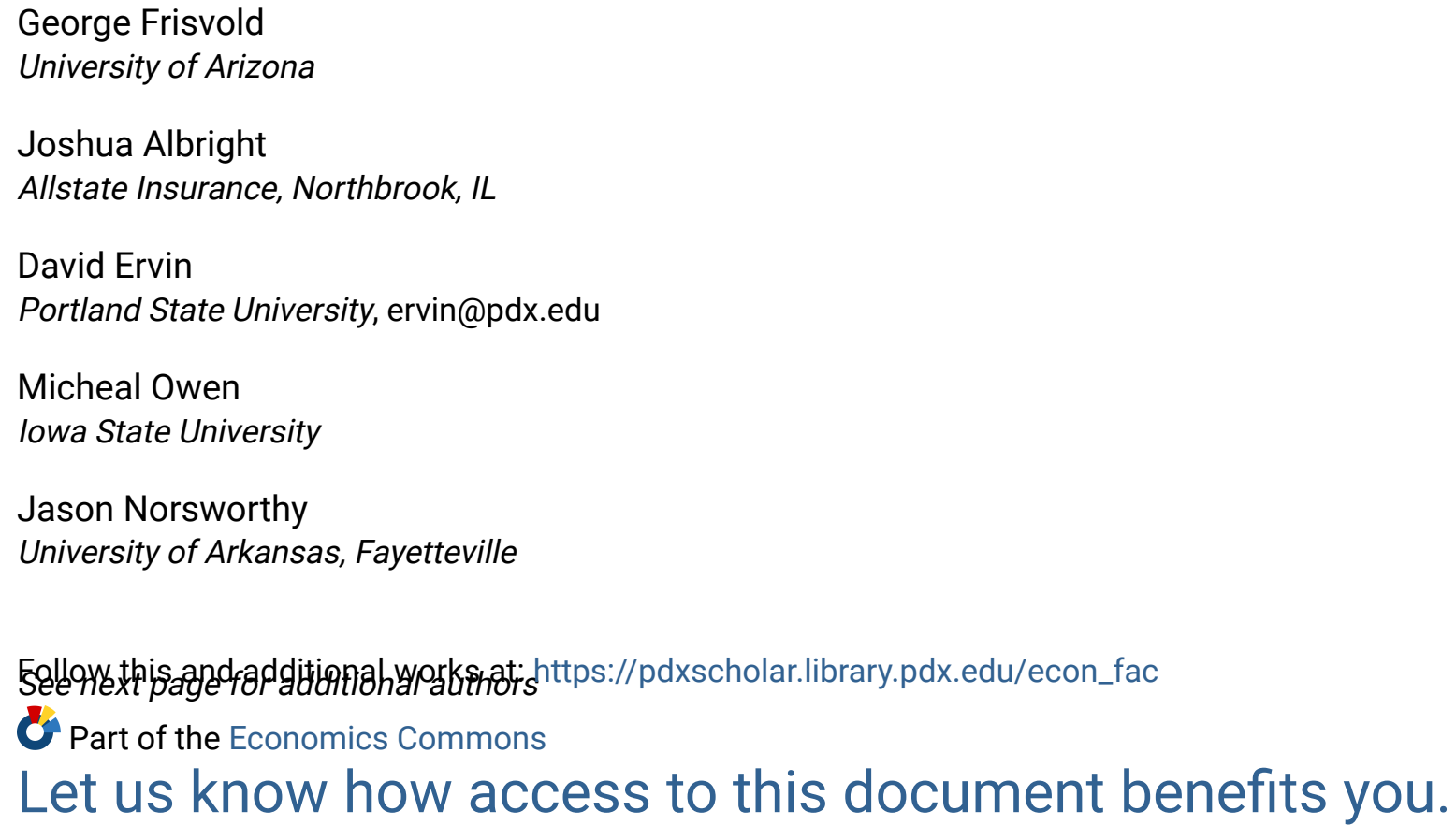

\section{Citation Details}

Frisvold, G. B., Albright, J., Ervin, D. E., Owen, M. D., Norsworthy, J. K., Dentzman, K. E., ... \& Everman, W. (2020). Do farmers manage weeds on owned and rented land differently? Evidence from US corn and soybean farms. Pest Management Science.

This Post-Print is brought to you for free and open access. It has been accepted for inclusion in Economics Faculty Publications and Presentations by an authorized administrator of PDXScholar. Please contact us if we can make this document more accessible: pdxscholar@pdx.edu. 


\section{Authors}

George Frisvold, Joshua Albright, David Ervin, Micheal Owen, Jason Norsworthy, Katherine E. Dentzman, Terrance M. Hurley, Raymond A. Jussaume, Jeffrey Gunsolus, and Wesley Everman 


\title{
Do farmers manage weeds on owned and rented land differently? Evidence from U.S. corn and soybean farms
}

\author{
George B. Frisvold, ${ }^{a}{ }^{*}$ Joshua Albright, ${ }^{b}$ David E. Ervin, ${ }^{c}$ Micheal D. K. \\ Owen, ${ }^{d}$ Jason K. Norsworthy, ${ }^{e}$ Katherine E. Dentzman, ${ }^{f}$ Terrance $M$. \\ Hurley, ${ }^{g}$ Raymond A. Jussaume, ${ }^{i}$ Jeffrey L. Gunsolus, ${ }^{\mathrm{h}}$ Wesley Everman ${ }^{\mathrm{j}}$
}

\begin{abstract}
BACKGROUND: It has been frequently argued that growers have less incentive to manage the evolution and spread of herbicide resistant weeds on leased than owned land. This is because resistance management provides long-term rather than short-term benefits that operators may be less assured of capturing on land they do not own. Yet, empirical evidence supporting this argument has been lacking.

RESULTS: This study reports on results from a large-scale national survey of weed management and other crop production practices on U.S. agricultural fields. Up to eleven weed management practices were compared across owner-operated versus renter-operated fields. Analysis of survey data from corn and soybean fields did not support the hypothesis that adoption of resistance manage practices is lower on rented acres. In most instances, there were no statistically significant differences in herbicide use or weed management practices on rented versus owned land. This was true at both national and regional levels of analysis. Where there were significant differences, practices associated with greater herbicide resistance management were, as often as not, more prevalent on rented than owned land.
\end{abstract}

CONCLUSIONS: A useful area of future research would be to test for land tenure differences in resistance management using multivariate analysis to control for confounding effects. Unobserved farmer or land characteristics may be confounding results and masking land tenure effects. Results here, however, suggest that these other effects are dominating any obvious disincentive effects of land leasing on resistance management. Of greater concern, the adoption of key resistance management practices was low on both owned and rented land.

Keywords: resistance management, weed management, adoption, land tenure, corn, soybeans

* Correspondence to: George Frisvold, Department of Agricultural and Resource Economics, 308 McClelland Park, 650 N. Park Ave. University of Arizona, Tucson, AZ, 85721, USA. E-mail:

frisvold@ag.ariozna.edu

a. Department of Agricultural \& Resource Economics, University of Arizona, Tucson, AZ, USA.

b. Allstate Insurance, Northbrook, IL, USA

c. Dept. of Economics and Dept. of Environmental Management, Portland State University, Portland, OR, USA

This article has been accepted for publication and undergone full peer review but has not been through the copyediting, typesetting, pagination and proofreading process which may lead to differences between this version and the Version of Record. Please cite this article as doi: $10.1002 /$ ps.5737 
d. Dept. of Agronomy, lowa State University, USA

e. Crop, Soil and Environmental Sciences, University of Arkansas, USA

f. Dept. of Agricultural Economics \& Rural Sociology, University of Idaho, USA

g. Dept. of Applied Economics, University of Minnesota, USA

h. Dept. of Sociology, Michigan State U, United States of America

i. Dept. of Agronomy and Plant Genetics, University of Minnesota, USA

j. Dept. of Weed Sciences, North Carolina State University, United States of America

1 INTRODUCTION

The continued growth in the number and geographic spread of herbicide-resistant (HR) weeds across North America may threaten farm profitability, lead to shifts in herbicides with more negative environmental profiles, or discourage environmentally beneficial farming practices such as conservation tillage. ${ }^{1}$ Yet, despite continued calls to action to promote resistance management practices, ${ }^{2,3}$ their adoption remains spotty. ${ }^{4-5}$

Several studies have suggested that farm operators have less incentive to adopt herbicide resistance management practices on land that is rented than on land that is owner-operated. ${ }^{6-11}$ This is because, while resistance management may be economically beneficial in the long-run, it can often be more expensive initially. Growers leasing land may be less assured of capturing these long-term benefits on land that they do not own (and are less likely to operate in the future).

More than half of U.S. corn and soybean acres are renter-operated, ${ }^{12}$ while nearly $40 \%$ of all land in farms is rented. ${ }^{13}$ If operating on rented land discourages resistance management, this disincentive effect could affect a lot of U.S. crop acreage. Farmers appear to share concern over such disincentive effects. The Herbicide Resistance Education Committee (HREC) of the Weed Science Society of America (WSSA) held 
several listening sessions around the United States to better understand farmer motivations, concerns, and challenges in adopting herbicide resistance management practices. ${ }^{14}$ Land tenure (whether a farmer owned or rented land) was among seven primary areas of economic concern that farmers identified.

Yet, despite this concern among researchers and farmers, there has been relatively little empirical work linking land tenure to adoption of resistance management practices. This study seeks to fill this information gap using data from a large-scale national survey of weed management and other crop production practices conducted by the U.S. Department of Agriculture (USDA).

\section{LAND TENURE AND INVESTING IN LAND PRODUCTIVITY}

It has long been argued that tenant farms have less incentive to maintain the productive capacity of the land they farm than do owner operators. ${ }^{15}$ This is because tenants are less assured that they will be able to operate rented land into the future and may not be able to capture returns on such near-term investments. Herbicide resistance management has been modeled conceptually as one such investment in longer-run productivity of cropland. ${ }^{4,16-18}$ Much of the empirical work on differences in incentives on rented versus owned land, however, has focused on soil conservation. Exploring this issue more formally, economists have developed theoretical optimization models of how tenancy can reduce soil conservation incentives, ${ }^{19-20}$ while rural sociologists have conducted structured interviews of tenants to assess how rental agreements can discourage land productivity investments. ${ }^{21-22}$ 
Yet, despite this research and despite the intuitive appeal that farmers take less care of the long-term productivity on rented land, the empirical evidence supporting this hypothesis is decidedly mixed. In six studies examined by Soule et al. ${ }^{20}$ adoption of conservation practices was greater on owned land in four studies, but not so in two. A later article,$^{23}$ examined 13 different studies assessing the effect of land tenure on conservation practice adoption; two supported the hypothesis, two refuted it, and nine found no significant relationship. A review of evidence from developing countries ${ }^{22}$ also yields contradictory findings as does a more recent review of the literature on the topic. ${ }^{24}$ Given the mixed results for various soil conservation practices, it is appropriate to formally examine the relationship between land tenure status and resistance management rather than take it as given that resistance management is practiced less on rented land.

\section{Materials and Methods}

The data used are reported by the USDA Economic Research Service (ERS) and come from USDA's Agricultural Resource Management Survey (ARMS) of USDA's National Agricultural Statistical Service (NASS). The NASS list sampling frame includes all known U.S. operations qualifying as a farm under the NASS definition and accounts for roughly $90 \%$ of total U.S. land in farms. Farms are defined as "all establishments that sold or would normally have sold at least $\$ 1,000$ of agricultural products during the year.” This excludes prison and research farms. ${ }^{25}$ The ARMS provides data on weed management and other crop production practices for selected commodities. USDA selects 
states to minimize the number of states surveyed, while ensuring that surveyed states account for at least $80 \%$ of U.S. target commodity acreage. Survey data were collected for corn production in 2010 and for soybean production in 2012. For the corn survey, 19 states were selected accounting for $93 \%$ of U.S. corn acreage, while for soybeans, 19 states were selected that accounted for $96 \%$ of U.S. soybean acreage.

ARMS is a multi-phase, multi-frame, stratified, and probability-weighted sample ${ }^{25}$ Phase 1 of the survey contacts farmers during the summer of the survey year. It asks whether respondents are farming or not and asks if the respondent is producing the commodities that the other phases of the survey may ask about. The response rate has ranged from $74 \%-77 \% .{ }^{26}$ This rate includes operations that responded but were out of scope of the survey. Phase 2 surveys a randomly selected group of farmers from Phase 1 , asking them about their crop production practices and agricultural chemical use. The Phase 2 response rate has ranged from $79 \%-81 \% .{ }^{26}$ Data used for the present study come from this Phase 2 survey. In the Phase 2 survey, individual fields are randomly selected from individual respondent farms. Then, detailed questions are asked about practices and production on that selected, individual field. ARMS targets about 5,000 fields each year.

For the specific, selected field, ARMS asks respondents if the field was owned by the operator or whether it was rented. For rented fields, the survey asks whether land was rented on a fixed cash basis, flexible cash basis, or rented in exchange for a share of the crop. Responses to questions about the type of rental agreement are not reported in publically 
available data used for the present study. Information is only publically available that distinguishes whether the field is owned and rented. No further distinction between types of rental agreements are available. For example, ARMS does not ask respondents about the length of rental agreements. If one thinks that insecurity of tenure discourages adoption of conservation practices, one might expect to see differences in behavior between shorter and longer term contracts. Unfortunately, such information is not collected in ARMS (at present). While $70 \%$ of U.S. farm leases are single-year contracts, $84 \%$ of U.S. farmland acres have been rented to the same tenant for over three years, suggesting lease renewal is common. ${ }^{13}$

ARMS relies on two sample frames. The first frame comes from a list of farms for which NASS has data, which can be helpful in sorting farms based on known variables. The second, geographic frame, can be useful in capturing farms that the list frame misses because of the change in farm ownership during the year in question or farms entering or exiting the market. Around 94\% of farms in the ARMS survey sample come from the list frame. ${ }^{25}$ The ARMS survey is also stratified by several variables which include production region or state, commodities produced, or farm size. Within each of these stratum, particular units are weighted, based on their selection probability.

To construct estimates of adoption of farm production practices, each survey unit is weighted by an expansion factor. Those weights are determined by the probability of an observation being sampled. Then using the weights, population estimates are calculated. A jackknife resampling process, ${ }^{27}$ which uses 30 different sets of weights for each sample to get 
an estimate for the variance of the first estimate. ${ }^{28-31}$ These 30 sets of weights will determine the degrees of freedom used when calculating statistics.

Data on weed management practices come from the 2010 survey for corn and 2012 survey for soybeans, both the most recent survey years for the respective crops. ${ }^{12}$ Data on eleven variables were available for corn and nine were available for soybeans:

1. Percentage of acres that were scouted for weeds

2. Percentage of acres where tilling, chopping, mowing, or burning was used to control pests (in the ARMS questionnaire, “pests” refers to weeds, insects, and diseases)

3. Percentage of acres where equipment was cleaned to reduce the spread of pests

4. Percentage of acres where farmers adjusted row spacing or plant density for pest control

5. Percentage of acres that were cultivated for weed control (corn only)

6. Average number of tillage operations

7. Average number of herbicide treatments

8. Herbicide treatment rate (pounds of active ingredient per treated acre)

9. Percentage of acres treated with a burndown herbicide

10. Percentage of acres receiving pre-emergence herbicide applications (corn only).

11. Percentage of acres where pesticides with different mechanisms of action were rotated or tank mixed for the primary purpose of keeping pests from becoming resistant to pesticides. 
We note some caveats about these questions as measures of herbicide resistance management. First, the ARMS uses the term "pests" to refer to insects and diseases as well as weeds. In these cases (e.g. questions 3, 4, and 11 above) the responses relate to resistance management generally, not just herbicide resistance management. Second, data on rotating or tank mixing pesticides with different mechanisms is self-reported by growers. Two factors can lead to over-reporting of adoption of these practices, relevant to resistance management. First, growers may be mistaken about whether various herbicides do indeed employ different mechanisms of action. Second, depending on the extent of resistance in a field, farmers may actually be applying fewer compounds with different effective mechanisms of action than they realize. As one study observes, "growers prefer to continue using a herbicide that provides effective control of susceptible weeds, only adding a second product when necessary to control resistant plants. This is not using different effective MOAs, as one of the two herbicides is no longer effective on all the weeds present.”32 Likewise, “cleaning equipment” is self-reported and provides no indication of the methods, timing, or thoroughness of cleaning.

With these limitations in mind, one can consider how the ARMS questions relate to resistance management. The first practice is whether the field was scouted for weeds. Scouting before herbicide applications aid growers in determining the types, abundance, and distribution of weed species to make applications more effective. Post-application scouting provides growers with information about the effectiveness of their treatments 
and potentially early indications of resistance problems. ${ }^{6,33}$ Questions 2-6 deal with various non-chemical, cultural practices that may delay resistance., ${ }^{6,33-38}$

Questions 7-11 deal with herbicide use and not necessarily directly with resistance management. For example, Questions 7 and 8 deal with frequency of herbicide applications and pounds of herbicide active ingredient per acre. Higher or lower values here could be consistent or inconsistent with resistance management depending on the local production context. For example, by applying the full, recommended label rate, one can mitigate low-dose selection for herbicide resistance. ${ }^{39}$ Yet, ARMS does not ask questions about whether label rates were followed as other surveys have. ${ }^{4}$ Burndown applications also have ambiguous implications for resistance management. Burndown applications may indicate a farmers is attempting to plant into a weed-free field or may be made in conjunction with planting cover crops, consistent with resistance management. ${ }^{6}$ Yet, past recommendations to use a burndown application of glyphosate followed by one or more glyphosate applications can increase the potential for resistance evolution. ${ }^{40}$ Likewise, use of pre-emergence herbicides with different mechanisms of action has been recommended to delay glyphosate resistance. ${ }^{16,41-43}$ Yet, pre-emergence application does not by itself guarantee effective resistance management.

With the exception of the average number of herbicide treatments, average pounds of active ingredient applied, and the average number tillage operations, all statistics are reported as the percentage of acres where a practice is adopted. Data are divided between fields 
that are rented and fields that are owner-operated. This allows for comparisons between practices on owned and rented fields. Data are reported at the national level and also broken down into farm production regions. Each observation in the data set also includes the residual standard error as a percentage of the estimate. Each of those are used to calculate normal standard errors that can be used to test for significant differences in variables.

To estimate each of the residual standard errors, ARMS uses the DAG (Delete-agroup) Jackknife variance estimator. ${ }^{28-31}$ When using the DAG Jackknife estimator, each of the estimates for standard errors have 29 degrees of freedom because of the 30 different sets of weights used to calculate the variances minus one. Thus when we calculate $\mathrm{t}$ statistics for testing a difference in means between owners and renters we must use degrees of freedom equal to 58 (2 time 29 degrees of freedom).

The method used to examine if weed management practices on owned fields differs from adoption on rented fields is a simple comparison of means to test for any statistically significant difference. A similar approach has been used to test differences in behavior across different farm types in previous studies on agritourism, vertical integration of agricultural enterprises, and management practice adoption among beef producers using ARMS data. ${ }^{44-46}$

A simple t-statistic is calculated. Because the ARMS uses the DAG jackknife variance estimator, degrees of freedom will equal 58 when we calculate the p-values for our tstatistic. Standard errors for each estimate are available in the data and are calculated using the 30 probability weighted estimates. The t statistics are calculated as: 


$$
\text { tstatistic }=\frac{\text { Estimate }_{\text {Owner }}-\text { Estimate }_{\text {Renter }}}{\sqrt{\text { Variance }_{\text {Owner }}+\text { Variance }_{\text {Renter }}}}
$$

Before turning to results, it is worth considering the economic situation growers faced in the years of the surveys (2010 and 2012). Compared to previous and subsequent years when ARMS data were collected, corn prices in 2010 and soybean prices in 2012 were considerably higher than in previous or subsequent survey years (Table 1).

\begin{tabular}{|c|c|c|c|c|c|}
\hline Corn & 2016 & 2010 & 2005 & 2001 & 1996 \\
\hline $\begin{array}{l}\text { Value of production less operating } \\
\text { costs (\$ / acre) }\end{array}$ & $\$ 263.37$ & $\$ 402.98$ & $\$ 74.06$ & $\$ 104.62$ & $\$ 208.98$ \\
\hline Price per bushel $(\$)$ & $\$ 3.29$ & $\$ 4.33$ & $\$ 1.74$ & $\$ 1.84$ & $\$ 2.82$ \\
\hline Herbicide price index $(2011=100)$ & 109.7 & 101.3 & 89.1 & 85.8 & 89.9 \\
\hline Herbicide price index / Corn price & 33.3 & 23.4 & 51.2 & 46.6 & 31.9 \\
\hline Soybeans & 2018 & 2012 & 2006 & 2002 & 1997 \\
\hline $\begin{array}{l}\text { Value of production less operating } \\
\text { costs }(\$ / \text { acre })\end{array}$ & $\$ 285.71$ & $\$ 424.53$ & $\$ 161.43$ & $\$ 134.50$ & $\$ 199.31$ \\
\hline Price per bushel $(\$)$ & $\$ 8.71$ & $\$ 14.21$ & $\$ 5.54$ & $\$ 5.20$ & $\$ 6.54$ \\
\hline Herbicide price index $(2011=100)$ & 101.7 & 106 & 94.2 & 85.3 & 89.9 \\
\hline Herbicide price index / Soybean price & 11.7 & 7.5 & 17.0 & 16.4 & 13.7 \\
\hline
\end{tabular}

Source: USDA, ERS, ${ }^{47}$ USDA, NASS ${ }^{48}$

Economists have developed theoretical models examining how land tenure can affect grower incentives to adopt conservation practices, which can have higher short run costs, but provide larger longer term benefits, with applications to soil conservation ${ }^{20}$ and herbicide resistance management. ${ }^{18}$ These models presume the probability of operating land in the future is one on owned land, but less than one on rented land. As such, economic incentives to adopt practices with long-term benefits are greater on owned land, assuming all other 
factors equal. Moreover, as output price increases, the gains to adoption increase relatively more for owned than rented land. Combined, these models and price conditions suggest that the 2010 and 2012 survey years were ones where the advantage of adopting resistance management practices on owned versus rented land would be relatively larger, all else equal.

Yet, average herbicide prices - as measured by USDA's herbicide price index ${ }^{48}$ were higher around 2010-2014 than in the previous two decades (Table 1). Some practices, such as making pre-emergence applications or rotating or tank mixing herbicides with different modes of action could involve using more or more expensive herbicides. Higher herbicide prices could discourage such practices. Studies have found costs to be important barriers to adoption of resistance management practices. ${ }^{49-53}$ There is some survey evidence that growers attach more significance on costs than even overall profitability as a constraint to resistance management. ${ }^{51,53}$ That said, net returns per acre were relatively high in the survey years, while the ratio of herbicide prices to crop prices was relatively low.

\section{Results and Discussion}

First, we consider how practices differ on owned and rented land at the national level for corn and soybean producers. To determine if differences in owned and rented fields are statistically significant, we calculate t statistics and associated p-values for corn (Table 2) and soybeans (Table 3).

Of the 11 variables compared for corn, there were statistically significant differences (at the 5\% level) between owned and rented acres in just two cases. Equipment was 
cleaned on a greater percentage of owned acres (37\%) than rented acres (30\%). In

contrast, using different mechanisms of action was practiced on a greater percentage of rented acres (30.5\%) than owned acres (24\%). 


\begin{tabular}{|c|c|c|c|c|}
\hline Weed Management Practice & Field Type & Estimate & S.E. & P-Value \\
\hline \multirow{2}{*}{ Percentage of acres scouted for weeds } & \multirow{2}{*}{$\begin{array}{l}\text { Owned } \\
\text { Rented }\end{array}$} & 87.31 & 1.29 & \multirow{2}{*}{0.26} \\
\hline & & 88.76 & 1.76 & \\
\hline \multirow{2}{*}{$\begin{array}{l}\text { Percentage of acres tilled, chopped, mowed, or } \\
\text { burned to control pests }\end{array}$} & Owned & 41.70 & 2.92 & \multirow{2}{*}{0.15} \\
\hline & Rented & 46.31 & 3.19 & \\
\hline \multirow{2}{*}{$\begin{array}{l}\text { Percentage of acres where equipment was } \\
\text { cleaned to reduce spread of pests }\end{array}$} & Owned & 37.19 & 2.86 & \multirow{2}{*}{0.04} \\
\hline & Rented & 30.29 & 2.69 & \\
\hline \multirow{2}{*}{$\begin{array}{l}\text { Percentage of acres where farmers adjusted row } \\
\text { spacing or plant density for pest control }\end{array}$} & Owned & 12.36 & 1.79 & \multirow{2}{*}{0.26} \\
\hline & Rented & 13.99 & 1.69 & \\
\hline \multirow[t]{2}{*}{ Average number of tillage operations } & Owned & 1.45 & 0.04 & \multirow[t]{2}{*}{0.36} \\
\hline & Rented & 1.39 & 0.06 & \\
\hline \multirow{2}{*}{ Percentage of acres cultivated for weed control } & Owned & 42.22 & 2.70 & \multirow{2}{*}{0.42} \\
\hline & Rented & 43.03 & 2.28 & \\
\hline \multirow{2}{*}{ Average number of herbicide treatments } & Owned & 2.80 & 0.07 & \multirow{2}{*}{0.21} \\
\hline & Rented & 2.89 & 0.09 & \\
\hline \multirow{2}{*}{$\begin{array}{l}\text { Herbicide treatment rate (pounds of active } \\
\text { ingredient per treated acre) }{ }^{a}\end{array}$} & Owned & 2.24 & 0.06 & \multirow{2}{*}{0.45} \\
\hline & Rented & 2.26 & 0.07 & \\
\hline \multirow{2}{*}{$\begin{array}{l}\text { Percentage of acres treated with a burndown } \\
\text { herbicide }\end{array}$} & Owned & 5.09 & 0.76 & \multirow[t]{2}{*}{0.46} \\
\hline & Rented & 4.97 & 0.81 & \\
\hline \multirow{2}{*}{$\begin{array}{l}\text { Percentage of acres where pesticides with } \\
\text { different mechanisms of action were rotated or } \\
\text { tank mixed }\end{array}$} & Owned & 24.21 & 2.57 & \multirow[b]{2}{*}{0.02} \\
\hline & Rented & 30.51 & 1.80 & \\
\hline \multirow{2}{*}{$\begin{array}{l}\text { Percentage of acres receiving pre-emergence } \\
\text { herbicide applications }\end{array}$} & Owned & 56.86 & 2.44 & \multirow{2}{*}{0.15} \\
\hline & Rented & 62.06 & 2.61 & \\
\hline
\end{tabular}

a. 1 pound $/$ acre $=1.12085 \mathrm{~kg} /$ ha. Source: USDA, ARMS

For soybeans (Table 3), non-chemical weed control methods where practiced on a higher percentage of acres on rented (than own) land. Only differences in scouting for weeds and 
adjusting row spacing or planting density were statistically significant at the $10 \%$ level (or lower), though. The number of herbicide treatments and pounds of active ingredient were greater on rented land, as was the percentage of acres where different mechanisms of action were employed to prevent resistance (again, significant at the $10 \%$ level). Greater underlying weed pressure on rented acres could contribute to these differences. We do not have data on differences in weed populations on owned versus rented land. Yet, it is questionable whether such a distinction at the level of national crop acreage would be meaningful.

\begin{tabular}{|c|c|c|c|c|}
\hline Weed Management Practice & Field Type & Estimate & S.E. & P-Value \\
\hline Percentage of acres scouted for weeds & $\begin{array}{l}\text { Owned } \\
\text { Rented }\end{array}$ & $\begin{array}{l}93 \cdot 31 \\
94.83\end{array}$ & $\begin{array}{l}0.65 \\
0.66\end{array}$ & 0.05 \\
\hline $\begin{array}{l}\text { Percentage of acres tilled, chopped, mowed or } \\
\text { burned to control pests }\end{array}$ & $\begin{array}{l}\text { Owned } \\
\text { Rented }\end{array}$ & $\begin{array}{l}42.7 \\
43.42\end{array}$ & $\begin{array}{l}1.79 \\
1.87\end{array}$ & 0.39 \\
\hline $\begin{array}{l}\text { Percentage of acres where equipment was } \\
\text { cleaned to reduce spread of pests }\end{array}$ & $\begin{array}{l}\text { Owned } \\
\text { Rented }\end{array}$ & $\begin{array}{l}33.87 \\
34.05\end{array}$ & $\begin{array}{l}2.37 \\
1.91\end{array}$ & 0.48 \\
\hline $\begin{array}{l}\text { Percentage of acres where farmers adjusted row } \\
\text { spacing or plant density for pest control }\end{array}$ & $\begin{array}{l}\text { Owned } \\
\text { Rented }\end{array}$ & $\begin{array}{l}16.44 \\
19 \cdot 34\end{array}$ & $\begin{array}{l}1.74 \\
1.28\end{array}$ & 0.09 \\
\hline Average number of tillage operations & $\begin{array}{l}\text { Owned } \\
\text { Rented }\end{array}$ & $\begin{array}{l}2.24 \\
2.28\end{array}$ & $\begin{array}{l}0.05 \\
0.05\end{array}$ & 0.28 \\
\hline Average number of herbicide treatments & $\begin{array}{l}\text { Owned } \\
\text { Rented }\end{array}$ & $\begin{array}{l}2.92 \\
3.02\end{array}$ & $\begin{array}{l}0.06 \\
0.05\end{array}$ & 0.08 \\
\hline $\begin{array}{l}\text { Herbicide treatment rate (pounds of active } \\
\text { ingredient per treated acre) }{ }^{a}\end{array}$ & $\begin{array}{l}\text { Owned } \\
\text { Rented }\end{array}$ & $\begin{array}{l}1.81 \\
1.90\end{array}$ & $\begin{array}{l}0.04 \\
0.03\end{array}$ & 0.04 \\
\hline $\begin{array}{l}\text { Percentage of acres treated with a burndown } \\
\text { herbicide }\end{array}$ & $\begin{array}{l}\text { Owned } \\
\text { Rented }\end{array}$ & $\begin{array}{l}32.63 \\
34.22\end{array}$ & $\begin{array}{l}1.60 \\
1.30\end{array}$ & 0.22 \\
\hline $\begin{array}{l}\text { Percentage of acres where pesticides with } \\
\text { different mechanisms of action were rotated or } \\
\text { tank mixed }\end{array}$ & $\begin{array}{l}\text { Owned } \\
\text { Rented }\end{array}$ & $\begin{array}{l}22.43 \\
25.48\end{array}$ & $\begin{array}{l}1.32 \\
1.86\end{array}$ & 0.09 \\
\hline
\end{tabular}

a. 1 pound $/$ acre $=1.12085 \mathrm{~kg} /$ ha. Source: USDA, ARMS 
We next examined the data disaggregated into different USDA farm production regions: Mountain (Arizona, Colorado, Idaho, Montana, Nevada, New Mexico, Wyoming, and Utah), Northern Plains (Kansas, Nebraska, North Dakota, South Dakota), Southern Plains (Oklahoma and Texas), Lake States (Michigan, Minnesota, Wisconsin), Corn Belt (Illinois, Indiana, Iowa, Missouri, Ohio), Northeast (Connecticut, Delaware, Maine, Maryland, Massachusetts, New Hampshire, New Jersey, New York, Pennsylvania, Rhode Island, Vermont), Appalachian (Kentucky, North Carolina, Tennessee, Virginia, West Virginia), Southeast (Alabama, Florida, Georgia, South Carolina), and Delta (Arkansas, Louisiana, Mississippi). Regions included in the ARMS survey differed for corn and soybeans, reflecting where production is concentrated.

More than half of corn and soybean acres in the United States are renter operated (Table 4). There is relatively little regional variation in this pattern. For corn, there are lower than average rates of rented acres in the Southeast, Northeast, and Lake States. The Southeast and Northeast, in particular though, account for a small share of corn acreage. For soybeans, rented acreages is more prevalent in the Delta and less prevalent in the Lake States. Deviations from the overall average of 56\% are small, however.

\begin{tabular}{|c|c|c|c|}
\hline \multicolumn{4}{|c|}{ Table 4. Owner Operated and Renter Operated Acres in U.S. Corn and Soybean Production } \\
\hline Corn (2010) & $\begin{array}{c}\text { Owner Operated } \\
\text { Acres (millions) }\end{array}$ & $\begin{array}{c}\text { Renter Operated } \\
\text { Acres (millions) }\end{array}$ & $\begin{array}{c}\text { Percentage Renter } \\
\text { Operated }\end{array}$ \\
\hline Mountain & 0.6 & 0.7 & $52 \%$ \\
\hline Northern Plains & 9.0 & 11.6 & $56 \%$ \\
\hline Southern Plains & 1.1 & 1.2 & $53 \%$ \\
\hline Lake States & 7.4 & 6.6 & $47 \%$ \\
\hline Corn Belt & 16.6 & 22.0 & $57 \%$ \\
\hline Northeast & 1.5 & 0.9 & $36 \%$ \\
\hline
\end{tabular}




\begin{tabular}{|l|r|r|l|} 
Appalachian & 1.1 & 1.2 & $52 \%$ \\
\hline Southeast & 0.2 & 0.1 & $34 \%$ \\
\hline Total Program States & 37.5 & 44.3 & $54 \%$ \\
\hline & & & \\
\hline Soybeans (2012) & & & $59 \%$ \\
\hline Northern Plains & 7.6 & 10.9 & $48 \%$ \\
\hline Lake States & 5.4 & 5.0 & $55 \%$ \\
\hline Corn Belt & 15.0 & 18.4 & $61 \%$ \\
\hline Delta & 2.5 & 3.8 & $54 \%$ \\
\hline Appalachian & 2.3 & 2.6 & $56 \%$ \\
\hline Total Program States & 32.7 & 40.8 & \\
\hline
\end{tabular}

Source: USDA, ARMS

Table 5 summarizes these results for corn. Because of the large amount of data for each practice and region, Table 5 only indicates whether a differences in means were statistically significant (at the 5\% or 1\% level) and whether the indicator variables were higher or lower on owned or rented land. With 8 regions and 11 variables, there were 88 potential t-tests of the data. However, data were unavailable at the regional level in 11 cases (leaving 77 possible tests). The regional data for corn do not show systematic relationships between land tenure and weed management behavior. Of 77 t-tests, statistically significant differences.

\begin{tabular}{|c|c|c|c|c|c|c|c|c|}
\hline Practice & $\begin{array}{l}\text { Moun- } \\
\text { tain }\end{array}$ & $\begin{array}{l}\text { No. } \\
\text { Plains }\end{array}$ & $\begin{array}{l}\text { So. } \\
\text { Plains }\end{array}$ & Lake & $\begin{array}{l}\text { Corn } \\
\text { Belt }\end{array}$ & $\begin{array}{l}\text { No. } \\
\text { East }\end{array}$ & $\begin{array}{l}\text { Appal- } \\
\text { achian }\end{array}$ & $\begin{array}{l}\text { So. } \\
\text { East }\end{array}$ \\
\hline \multicolumn{9}{|l|}{$\begin{array}{l}\text { Percentage of acres } \\
\text { scouted for weeds }\end{array}$} \\
\hline $\begin{array}{l}\text { Percentage of acres tilled, } \\
\text { chopped, mowed, or } \\
\text { burned to control pests }\end{array}$ & & & & & $R *$ & & & \\
\hline $\begin{array}{l}\text { Percentage of acres where } \\
\text { equipment was cleaned to } \\
\text { reduce spread of pests }\end{array}$ & & & & & & $x$ & & $\mathrm{R}$ * \\
\hline $\begin{array}{l}\text { Percentage of acres where } \\
\text { farmers adjusted row }\end{array}$ & $x$ & & $x$ & & & & & $x$ \\
\hline
\end{tabular}




\begin{tabular}{|c|c|c|c|c|c|c|}
\hline \multicolumn{7}{|l|}{$\begin{array}{l}\text { spacing or plant density for } \\
\text { pest control }\end{array}$} \\
\hline \multicolumn{7}{|l|}{$\begin{array}{l}\text { Average number of tillage } \\
\text { operations }\end{array}$} \\
\hline \multicolumn{7}{|l|}{$\begin{array}{l}\text { Percentage of acres } \\
\text { cultivated for weed control }\end{array}$} \\
\hline $\begin{array}{l}\text { Average number of } \\
\text { herbicide treatments }\end{array}$ & & $\mathrm{R} * *$ & & & & \\
\hline \multicolumn{7}{|l|}{$\begin{array}{l}\text { Herbicide treatment rate } \\
\text { (pounds of active ingredient } \\
\text { per treated acre) }^{a}\end{array}$} \\
\hline $\begin{array}{l}\text { Percentage of acres treated } \\
\text { with a burndown herbicide }\end{array}$ & & & & $x$ & $\mathrm{R}$ * & $X$ \\
\hline $\begin{array}{l}\text { Percentage of acres where } \\
\text { pesticides with different } \\
\text { mechanisms of action } \\
\text { were rotated or tank } \\
\text { mixed }\end{array}$ & $x$ & $x$ & & & $x$ & $x$ \\
\hline $\begin{array}{l}\text { Percentage of acres } \\
\text { receiving pre-emergence } \\
\text { herbicide applications } \\
\end{array}$ & $x$ & & $\mathrm{R}$ * & & & \\
\hline \multicolumn{7}{|c|}{$\begin{array}{l}\text { Blank cells indicates there was no statistically significant difference in means. } \\
\text { " } \mathrm{X} \text { " indicates that the t-test could not be performed due to missing data. } \\
\text { "O" indicates adoption rates or averages on owned land are higher. } \\
\text { "R" indicates adoption rates or averages on rented land are higher } \\
\text { Significance level of t-test: }{ }^{*}=5 \%^{* *}=1 \%\end{array}$} \\
\hline
\end{tabular}

a. 1 pound $/$ acre $=1.12085 \mathrm{~kg} /$ ha. Source: USDA, ARMS

in practices between owned and rented land were found (at the 5\% level or lower) in only

five cases (6.4\% of the total). Looking at just the top six rows of Table 5, which deal with

non-chemical practices, there were only two cases with significant differences. But, in these

two cases (tilling, chopping, etc. in the Corn Belt and cleaning equipment in the Southeast)

adoption rates were higher on rented acreage.

Table 6. Differences in weed management practices for owned and rented soybean fields, 2012 data disaggregated by USDA farm production region

\begin{tabular}{|l|c|c|c|c|c|} 
& $\begin{array}{c}\text { Northern } \\
\text { Plains }\end{array}$ & Lake & Corn Belt & Delta & Appalachian \\
\hline
\end{tabular}




\begin{tabular}{|l|l|l|l|l|l|}
\hline Percentage of acres scouted for weeds & $\mathrm{R} * *$ & $\mathrm{O} *$ & & & \\
\hline $\begin{array}{l}\text { Percentage of acres tilled, chopped, } \\
\text { mowed, or burned to control pests }\end{array}$ & & & & & \\
\hline $\begin{array}{l}\text { Percentage of acres where equipment } \\
\text { was cleaned to reduce spread of pests }\end{array}$ & $\mathrm{R} *$ & & & & \\
\hline $\begin{array}{l}\text { Percentage of acres where farmers } \\
\text { adjusted row spacing or plant density for } \\
\text { pest control }\end{array}$ & $\mathrm{R} *$ & & & & \\
\hline Average number of tillage operations & & & & & \\
\hline $\begin{array}{l}\text { Average number of herbicide } \\
\text { treatments }\end{array}$ & & & & & \\
\hline $\begin{array}{l}\text { Herbicide treatment rate (pounds of } \\
\text { active ingredient per treated acre) }\end{array}$ & & & & & \\
\hline $\begin{array}{l}\text { Percentage of acres treated with a } \\
\text { burndown herbicide }\end{array}$ & & & & & \\
\hline $\begin{array}{l}\text { Percentage of acres where pesticides } \\
\text { with different mechanisms of action } \\
\text { were rotated or tank mixed }\end{array}$ & & & & & \\
\hline $\begin{array}{l}\text { Blank cells indicates there was no statistically significant difference in means. } \\
\text { "X" indicates that the t-test could not be performed due to missing data. } \\
\text { "O" indicates adoption rates or averages on owned land are higher. } \\
\text { "R" indicates adoption rates or averages on rented land are higher } \\
\text { Significance level of t-test: * }=5 \% * * 1 \%\end{array}$ & & & \\
\hline
\end{tabular}

a. 1 pound $/$ acre $=1.12085 \mathrm{~kg} /$ ha. Source: ARMS

For soybeans (Table 6), 45 t-tests were performed (given 9 practices and 5 regions). Of 45 t-tests, statistically significant differences (at the 5\% level or lower) on owned versus rented land were found in only four cases ( $<9 \%$ of the total). Looking at the top five rows of Table 6, which again deal with non-chemical practices, there was just one case where the adoption rate was higher on owned acres (weed scouting in the Lake states), while adoption was higher on rented acres for weed scouting, cleaning equipment, and adjusting row spacing, all in the Northern Plains. 
In sum, examining both regional and national corn and soybean data, in most cases there were no significant differences in weed management practices across owned and rented land. Further, the results presented in Tables 2, 3, 5, and 6 do not adjust for the fact that in presentations of such multiple tests, on the probability of getting a significant result simply by chance increases with the number of tests. Thus in Table 2, the probability of at least one false positive (significant difference even if the null hypothesis of no difference is true, or type I error) based on a $5 \%$ significance level would be 0.43 , given 11 tests presented $\left[1-(1-0.05)^{11}=0.43\right]$. For Table 3 , presenting nine tests, the probability of observing least one of one false positive with a $10 \%$ significance level would be $0.61\left[1-(1-0.10)^{9}=0.61\right]$. For Tables 4 and 5 the probability of observing at least one false positive (at the 5\% level) are 0.98 and 0.90 .

Statisticians and applied practitioners have debated the appropriateness of imposing corrections on significance levels to reduce the probability of type I errors. ${ }^{54}$ Corrections (such as the Bonferroni correction) can reduce the probability of type I error, but at the expense of increasing the probability of type II errors (i.e., in our case, not observing a significant difference on owned and rented land where one actually existed). A critical consideration is whether one is worried about type I errors more than type II ones. ${ }^{54}$ In this study, we found very few statistically significant differences, even without corrections for type I error. So, even though one could argue that our procedures are biased in favor of finding relationships between land tenure and weed management, 
generally we still do not. Our main finding - that there is little clear evidence that behavior on owned and rented fields differs - is only bolstered when one considers that there is a high probability that some of the (small number of) observed differences are merely due to chance. Moreover, in the few cases where there were statistically significant differences, more often than not, adoption rates associated with better resistance management were higher on rented acres than owned acres.

The ARMS results are consistent with the limited evidence from other studies on land tenure and herbicide resistance management. In the 2012 through 2014 versions of Iowa Farm and Rural Life Poll, 42\% of farmer respondents disagreed or strongly disagreed that farmers were less likely to use good resistance management practices on rented land, $29 \%$ of respondents agreed or strongly agreed, and 29\% were uncertain..$^{55}$ In the 2017 Iowa poll, ${ }^{56} 67 \%$ of respondents said they disagreed or strongly disagreed with the statement, "I am more concerned about herbicide resistance on my own land than on land that I rent.” Just 7\% strongly agreed, while $14 \%$ agreed, and $12 \%$ were uncertain. More detailed analysis from 2012-14 Iowa poll data found that farmer adoption of resistance management practices was positively associated with a higher percentage cropland rented. ${ }^{57-58}$ An earlier multivariate regression study of corn, cotton, and soybean farmers found no significant association between the percentage of cropland owned and the total number of resistance management practices adopted often or always. ${ }^{4}$ Considering ten resistance management practices separately, the study found no significant relationship in eight cases. Scouting 
before applying herbicides was positively associated with the percentage of land owned, while starting with a clean field was negatively associated the share of land owned.

Given the significant share of U.S. cropland that is leased, any disincentive effects of tenancy on resistance management could affect a significant share of U.S. acreage. In terms of policy implications, combating such disincentive effects (if they exist), might require greater outreach to agricultural land owners that lease out their land. Given that nearly a third U.S. farmland is leased out by non-operators, ${ }^{13}$ this would require additional extension efforts (and resources) to reach this audience.

Analyses of the ARMS data find no evidence of systematic negative effects of renting land on adoption of herbicide resistance management. But, absence of evidence is not evidence of absence. As has been noted in discussion of ambiguous findings on land tenure and soil conservation ${ }^{59}$ there are multiple differences in farmer and farm characteristics that are not being controlled which can muddy results. Unobserved farmer or land characteristics may be confounding results and masking land tenure effects.

To partially account for confounding effects of the presence of herbicide resistant weeds, we experimented with using the regional data to regress practice adoption on a land tenure indicator variable and measures of the prevalence of herbicide resistant weeds. ${ }^{60}$ Even when attempting to control for such prevalence, the land tenure indicator was never statistically significant. Yet, the number of observations for the 11 practice adoption regressions was quite small (28 or fewer) and the level of analysis is highly aggregated 
(across multi-state regions). Accounting for the presence of resistant weeds on grower behavior is likely to show more promise using farm-level data sets. ${ }^{5}$

Data from the most recent Census of Agriculture breaks farmer characteristics down by tenure of the farm operation, splitting operations into full owners (no land leased in), tenants (operating only leased in land) and partial owners (operating a combination of owned and leased in land). ${ }^{61}$ Compared to partial owners and tenants, full owners (who account for a third of all land in farms) operate fewer acres, have lower sales, have lower net farm income, are older on average, and are more likely to report off-farm work as their principal occupation. It is possible that factors such as small scale of operation, lack of time (because of high off-farm work commitments), or age (shorter time horizon) discourage resistance management by full owners. Examination of these issues is beyond the scope of the present analysis relying on publically available, aggregated ARMS data. Yet, a useful area of future research would be to test for land tenure differences in resistance management using multivariate analysis to control for confounding effects.

Another useful area of future research would be to update this analysis when new ARMS data become available for more recent years. The incidence of herbicide resistant weeds and grower awareness of them have grown since the time these surveys were conducted. New herbicide-resistant weed species have increased at a rate of four new cases per year since $2002 .{ }^{62}$ 
There is some evidence from grower attitude surveys that concern about HR weeds has grown, while confidence that industry will provide new products has lessened. A 20052006 survey of 1,200 U.S. growers found that 39\% or fewer thought glyphosate resistance was a serious issue, while fewer than one in five had personally experienced glyphosate resistant weeds on their farms. ${ }^{63}$ A 2007 survey asked growers an open-ended question regarding their biggest concerns in terms of weed management. ${ }^{64}$ An indicator variable was constructed equal to 1 if the grower reported any concern with weed resistance and 0 otherwise. About $54 \%$ of soybean and $48 \%$ of corn growers mentioned resistance concerns. Another earlier survey of Indiana growers found only 36\% expressed a high level of concern about weed resistance, with $19 \%$ expressing low or no concern. ${ }^{65}$

More recently, though, a 2015 survey found that $71 \%$ of growers were concerned about HR weeds spreading to their farms from nearby operations. ${ }^{5}$ For the question, "How concerned are you about the presence of weeds resistant to multiple herbicides on your farming operation?” with a 4-point Likert scale: $1=$ not concerned at all, 2=not very concerned, $3=$ somewhat concerned, $4=$ very concerned, the mean of responses was $3.46 .{ }^{5}$ In a 2016 survey of Corn Belt soybean producers, 97\% agreed or strongly agreed that they were concerned about glyphosate resistance. Two thirds had fields infested with glyphosate-resistant weeds, while nearly three quarters agreed or strongly agreed that glyphosate resistance presents a serious problem to their farming operation. ${ }^{66}$ 
A survey of 400 U.S. corn, soybean and cotton growers found 92\% respondents were "somewhat" to "very confident" that chemical manufacturers would develop new products to address glyphosate resistance with 3-5 years. ${ }^{67}$ More recent surveys do not suggest this level of confidence. A 2015 survey of more than 500 U.S. field crop growers asked the question, "By the time a weed develops resistance to an herbicide, at least one new herbicide will have been found to replace it,” with a Likert Scale response: 1=strongly disagree, $2=$ somewhat disagree, $3=$ neither agree nor disagree, $4=$ somewhat agree, 5=strongly agree. The mean score of respondents was $2.39 .{ }^{5}$ In a 2016 survey of 725 Midwestern U.S. soybean growers, $64 \%$ of respondents disagreed or strongly disagreed that resistant weeds were not a problem because new technologies would be developed to manage them. ${ }^{66}$ In a recent survey in Nebraska, $60 \%$ of growers in Nebraska reported the presence one or more glyphosate-resistant weed species on their farms. Rating GR weeds on a $0-10$ scale ( 0 , not at all a problem to 10 , highly problematic), the average score was 7.4 , with the median, 8 , suggesting a high level of concern. ${ }^{68}$

The 2010 Corn and 2012 Soybean ARMS data are the most recent available reporting practice adoption by field ownership status. Data from 2018 are publically available for selected weed management practices from the USDA, NASS Agricultural Chemical Use Program $^{67}$ (Table 5). Weed scouting, already high for soybeans has increased for corn. Adoption of non-chemical practices (i.e. cleaning equipment, adjusting row spacing / planting densities, and tilling, chopping, etc.) all show greater rates of adoption for both 
corn and soybeans. While use of pesticides with different modes of action to prevent resistance were adopted on a higher percentage of acres in 2018 than in 2010 or 2012, this practice is still followed on less than half of U.S. corn and soybean acres.

\begin{tabular}{|l|r|r|r|r|}
\hline \multicolumn{4}{|l|}{ Table 7. Adoption of Selected Weed Practices: Study Years Versus 2018 Data } \\
\hline & Corn (\% of acres) & \multicolumn{2}{|c|}{ Soybeans (\% of acres) } \\
\hline Practice & 2010 & 2018 & 2012 & 2018 \\
\hline Tilling, chopping, mowing, burning to control pests & 44 & 56 & 43 & 52 \\
\hline Clean equipment to reduce spread of pests & 33 & 43 & 34 & 40 \\
\hline $\begin{array}{l}\text { Pesticides with different mechanisms of action } \\
\text { were rotated or tank mixed }\end{array}$ & 28 & 44 & 24 & 40 \\
\hline Adjust row spacing/plant density for pest control & 13 & 18 & & 18 \\
\hline Field scouted for weeds & 88 & 94 & 94 & 94 \\
\hline
\end{tabular}

Source: USDA, NASS ${ }^{69}$

\section{Conclusion}

It has been suggested that farmers are less likely to adopt herbicide resistance management practices on rented land as opposed to land they own. Analysis of USDA Agricultural Resource Management Survey (ARMS) data for corn and soybeans, in general did not support this hypothesis. Disaggregating the ARMS data by USDA farm production region did not change this result. As often as not, individual resistance management practices were adopted more frequently on rented acreage. Given the univariate statistical tests used in this study, more research is needed to control for potential confounding effects of farm and farmer characteristics. Results here, however, suggest that these other effects are dominating any obvious disincentive effects of land leasing on resistance management. Yet, these results are from 2010-2012. Since that time, there is evidence that growers have greater experience with resistant weeds and are more concerned about them. So it 
would be of interest to examine this research problem in a multivariate regression setting with more recent data.

It is concerning that adoption of key resistance management practices was low on both owned and rented land. For example, the practices of rotating or tank mixing pesticides with different "mechanisms of action" (the term used in the ARMS survey) to keep pests from evolving resistance to pesticides was practiced on less than a third of U.S. corn acres and fewer than a quarter of U.S. soybean acres. More recent USDA data suggests that these rates have increased to $40 \%$ of U.S. soybean and $44 \%$ of U.S. corn acres. While an improvement, these adoption rates are still quite low. This is especially disconcerting considering that these results are based on farmer self-reporting and that farmers may well be overstating their use of different effective mechanisms of action. ${ }^{32}$ 


\section{References}

1. Pannell DJ, Tillie P, Rodríguez-Cerezo E, Ervin D, Frisvold GB. Herbicide resistance: Economic and environmental challenges. AgBioForum, 19: 136-155 (2016).

2. Duke SO, Powles SB. Glyphosate: a once-in-a-century herbicide. Pest Manag Sci 64:319-25 (2008).

3. Coble HD, Schroeder J. Call to action on herbicide resistance management. Weed Sci 64:661-6 (2016).

4. Frisvold, GB, Hurley TM, and Mitchell PD. Adoption of best management practices to control weed resistance by corn, cotton, and soybean growers. AgBioForum 12:370-381 (2009).

5. Ervin DE, Breshears EH, Frisvold GB, Hurley TM, Dentzman KE, Gunsolus JL, Jussaume RA, Owen MD, Norsworthy JK, Al Mamun MM, Everman W. Farmer attitudes toward cooperative approaches to herbicide resistance management: A common pool ecosystem service challenge. Ecol Econ 157:237-45 (2019).

6. Norsworthy JK, Ward SM, Shaw DR, Llewellyn RS, Nichols RL, Webster TM, Bradley KW, Frisvold G, Powles SB, Burgos NR, Witt WW. Reducing the risks of herbicide resistance: best management practices and recommendations. Weed Sci 60:31-62 (2012).

7. Owen MD, Beckie HJ, Leeson JY, Norsworthy JK, Steckel LE. Integrated pest management and weed management in the United States and Canada. Pest Manag Sci 71:357-76 (2015).

8. Rubione C, Ward SM. A new approach to weed management to mitigate herbicide resistance in Argentina. Weed Sci 64:641-8 (2016).

9. Shaw DR. The "wicked" nature of the herbicide resistance problem. Weed Sci 64:552-8 (2016).

10. Rubione C. Can herbicide resistance evolve due to factors other than a repeated use of technology? Argentina, A case to consider. Outlooks on Pest Manag 28:213-9 (2017).

11. Desquilbet M, Bullock DS, D’Arcangelo FM. A discussion of the market and policy failures associated with the adoption of herbicide-tolerant crops. Int J Ag Sustainability 14:1-2 (2019).

12. USDA, ERS. 2019. ARMS Farm Financial and Crop Production Practices: Tailored Reports: Crop Production Practices https://data.ers.usda.gov/reports.aspx?ID=17883 (accessed 8/29/2019).

13. Bigelow D. Farmland ownership and tenure in D. Hellerstein, D. Vilorio, and M. Ribaudo (eds). Agricultural Resources and Environmental Indicators, 2019. EIB-208, U.S. Department of Agriculture, Economic Research Service. (2019).

14. Schroeder J, Barrett M, Shaw DR, Asmus AB, Coble H, Ervin D, Jussaume RA, Owen MD, Burke I, Creech CF, Culpepper AS. Managing wicked herbicide-resistance: Lessons from the field. Weed Tech 32:475-88 (2018).

15. Ely RT, Morehouse EW. Elements of land economics. Macmillan, New York; 1926. 
16. Livingston M, Fernandez-Cornejo J, Frisvold GB. Economic returns to herbicide resistance management in the short and long run: the role of neighbor effects. Weed Sci 64:595-608 (2016).

17. Frisvold GB, Bagavathiannan MV, Norsworthy JK. Positive and normative modeling for Palmer amaranth control and herbicide resistance management. Pest Manag Sci 73:1110-20 (2017).

18. Albright JF. (2016). Herbicide resistant weeds: Owner/renter behavior and hazard model analysis. M.S. Thesis, Department of Agricultural and Resource Economics. University of Arizona. Tucson, Arizona.

19. McConnell KE. An economic model of soil conservation. Amer J Ag Econ 65:83-9 (1983).

20. Soule MJ, Tegene A, Wiebe KD. 2000. Land tenure and the adoption of conservation practices. Amer J Ag Econ 82:993-1005 (2000).

21. Carolan MS. Barriers to the adoption of sustainable agriculture on rented land: An examination of contesting social fields. Rural Sociology 70:387-413 (2005).

22. Leonhardt H, Penker M, Salhofer K. Do farmers care about rented land? A multi-method study on land tenure and soil conservation. Land Use Policy 82:228-39 (2019).

23. Knowler D, Bradshaw B. Farmers' adoption of conservation agriculture: A review and synthesis of recent research. Food Policy 32:25-48 (2007).

24. Liu T, Bruins R, Heberling M. Factors influencing farmers' adoption of best management practices: A review and synthesis. Sustainability 10:432 (2018).

25. U.S. Department of Agriculture. Economic Research Service. 2019. ARMS Farm Financial and Crop Production Practices: Documentation. https://www.ers.usda.gov/dataproducts/arms-farm-financial-and-crop-production-practices/documentation/\#Scope (accessed 8/29/2019).

26. National Research Council. Understanding American agriculture: challenges for the agricultural resource management survey. National Academies Press. Washington, DC. 2007.

27. Shao J, Wu CJ. A general theory for jackknife variance estimation. Annals of Statistics 17:1176-97 (1989).

28. Kott PS. Using the delete-a-group jackknife variance estimator in NASS surveys. US Department of Agriculture, National Agricultural Statistics Service, Research Division; 1998 Mar. NASS Research Report, RD-98-01 (Revised July 2001).

29. Kott PS. The delete-a-group jackknife. J Official Statistics 17:521-526 (2001).

30. Kott PS. 2008. Building a Better Delete-A-Group Jackknife for a Calibration Estimator (Like that Based on Data from the ARMS III). Extension of paper presented at the Workshop on Calibration and Estimation in Surveys, Ottawa, Ontario, October / November 2007.

31. Dubman R. 2000. Variance Estimation with USDA's Farm Costs and Returns Surveys and Agricultural Resource Management Study Surveys (No. 1486-2018-5538). 
32. Shaw DR, Norsworthy JK, Ward SM. Best management practices to prevent, delay, or manage herbicide resistance. Outlooks Pest Manag 24:132-5 (2013).

33. Beckie HJ, Harker KN. Our top 10 herbicide-resistant weed management practices. Pest Manag Sci 73:1045-52 (2017).

34. Owen MD. Diverse approaches to herbicide-resistant weed management. Weed Sci 64:570-84 (2016).

35. Norsworthy JK, Oliver LR. Effect of seeding rate of drilled glyphosate-resistant soybean (Glycine max) on seed yield and gross profit margin. Weed Tech 15:284-292 (2001).

36. Norsworthy JK, Oliver LR. Effect of irrigation, soybean (Glycine max) density, and glyphosate on hemp sesbania (Sesbania exaltata) and pitted morningglory (Ipomoea lacunosa) interference in soybean. Weed Tech 16:7-17 (2002).

37. Norsworthy JK, Frederick JR. Integrated weed management strategies for maize (Zea mays) production on the southeastern coastal plains of North America. Crop Prot 24:119-126 (2005).

38. Walsh MJ, Powles SB. Management strategies for herbicide resistant weed populations in Australian dryland crop production systems. Weed Tech 21:332-338 (2007).

39. Gressel J. Low pesticide rates may hasten the evolution of resistance by increasing mutation frequencies. Pest Manag Sci 67:253-257 (2011).

40. Shaner DL. The impact of glyphosate - tolerant crops on the use of other herbicides and on resistance management. Pest Manag Sci 56:320-326 (2000).

41. Beckie HJ. Herbicide-resistant weed management: focus on glyphosate. Pest Manag Sci 67:1037-48 (2011).

42. Weirich JW, Shaw DR, Owen MD, Dixon PM, Weller SC, Young BG, Wilson RG, Jordan DL. Benchmark study on glyphosate-resistant cropping systems in the United States. Part 5: Effects of glyphosate-based weed management programs on farm- level profitability. Pest Manag Sci. 67:781-4 (2011).

43. Wilson RG, Young BG, Matthews JL, Weller SC, Johnson WG, Jordan DL, Owen MD, Dixon PM, Shaw DR. Benchmark study on glyphosate - resistant cropping systes in the United States. Part 4: Weed management practices and effects on weed popualtions and soil seedbanks. Pest Manag Sci 67:771-80 (2011)

44. Bagi FS, Reeder RJ. Factors affecting farmer participation in agritourism. Agricultural and Resource Econ Rev 41:189-99 (2012).

45. Pruitt JR, Gillespie JM, Nehring RF, Qushim B. Adoption of technology, management practices, and production systems by US beef cow-calf producers. J Ag Applied Econ 44:203-22 (2012).

46. Azzam A. Testing for Vertical Economies of Scope: An Example from Hog Production. J Ag Econ 49:427-533 (1998).

47. U.S Department of Agriculture. Economic Research Service. 2019. Data Products: Commodity Costs and Returns data. https://www.ers.usda.gov/data-products/commoditycosts-and-returns (accessed November 13, 2019). 
48. U.S. Department of Agriculture. National Agricultural Statistical Service. Quick Stats data base. Herbicides - Index of Prices Paid, 2011. https:/quickstats.nass.usda.gov/ (accessed November 13, 2019).

49. Hurley TM, Mitchell PD, Frisvold GB. Weed management costs, weed best management practices, and the Roundup Ready ${ }^{\circledR}$ weed management program. AgBioForum 12:281290 (2009).

50. Weirich JW, Shaw DR, Owen MD, Dixon PM, Weller SC, Young BG, Wilson RG, Jordan DL. Benchmark study on glyphosate-resistant cropping systems in the United States, part 5: effects of glyphosate-based weed management programs on farm level profitability. Pest Manag Sci 67:781-784 (2011).

51. Riar DS, Norsworthy JK, Steckel LE, Stephenson DO, Eubank TW, Bond J, Scott RC Adoption of best management practices for herbicide-resistant weeds in midsouthern United States cotton, rice, and soybean. Weed Tech 27:788-797 (2013).

52. Hurley TM, Frisvold G. Economic barriers to herbicide-resistance management. Weed Sci, 64:585-594 (2016).

53. Schwartz-Lazaro LM, Norsworthy JK, Steckel LE, Stephenson DO, Bish MD, Bradley KW, Bond JA. A midsouthern consultant's survey on weed management practices in soybean. Weed Tech 32:116-125 (2018).

54. Armstrong RA. When to use the Bonferroni correction. Ophth \& Phys Optics 34:502-508 (2014).

55. Arbuckle JG Jr., Sternweis L. 2014. Farmer Perspectives on Pesticide Resistance: New Report from Iowa Farm and Rural Life Poll. Ames, IA: Iowa State University Extension and Outreach PM 3070. 9 p.

56. Arbuckle JG Jr. 2017. Iowa Farm and Rural Life Poll: 2017 Summary Report. Ames, IA: Iowa State University Extension and Outreach. SOC 3085. 20 p.

57. Miranowski JA. Intervention to manage pest resistance: community-based or government regulation. Choices 31:1-8 (2016).

58. Diaz-Rivera R. Miranowski J. 2016. “Socioeconomic Factors Determining Integrated Weed Management Adoption by Iowa Corn and Soybean Farmers.” Paper presented at the 20th ICABR Conference: Transforming the Bioeconomy: Behavior, Innovation and Science, Ravello, Italy.

59. Ervin DE. 1986. Constraints to Practicing Soil Conservation: Land Tenure Relationships. In SB Lovejoy and TL Napier, eds., Conserving Soil: Insights from Socioeconomic Research. Ankeny, Iowa: Soil Conservation Society of America.

60. Heap IM (2019) International Survey of Herbicide Resistant Weeds. http://www.weedscience.org/. Accessed November 1, 2019

61. U.S. Department of Agriculture. 2017 Census of Agriculture. United States Summary and State Data. Volume 1, Geographic Area Series, Part 51, AC-17-A-51.

62. Kniss AR. Genetically engineered herbicide-resistant crops and herbicide-resistant weed evolution in the United States. Weed Sci 66:260-273 (2018). 
63. Johnson WG, Owen MDK, Kruger GR, Young BG, Shaw DR, Wilson RG, et al., U.S. farmer awareness of glyphosate-resistant weeds and resistance management practices. Weed Tech 23:308-310 (2009).

64. Hurley TM, Mitchell PD, Frisvold GB. Effects of weed-resistance concerns and resistance-management practices on the value of Roundup Ready ${ }^{\circledR}$ crops. AgBioForum 12:291-302 (2009).

65. Johnson WG., Gibson KD. Glyphosate-resistant weeds and resistance management strategies: An Indiana grower perspective. Weed Tech 20:768-772 (2006).

66. Southard E, Lindberg S, Bain C. 2017. Midwestern Soybean Farmers' Perceptions and Management of Glyphosate Resistant Weeds. SOC 3084. Department of Sociology, Iowa State University, Ames, Iowa. 12 pp.

67. Foresman C, Glasgow L. US grower perceptions and experiences with glyphosateresistant weeds. Pest Manag Sci 64:388-391 (2008).

68. Sarangi D, Jhala AJ. 2018. A statewide survey of stakeholders to assess the problem weeds and weed management practices in Nebraska. Weed Technology, 32(5):642-655.

69. U.S. Department of Agriculture, National Agricultural Statistical Service (USDA, NASS). 2019. Agricultural Chemical Use Program. https://www.nass.usda.gov/Surveys/Guide_to_NASS_Surveys/Chemical_Use/ accessed November 11, 2019). 